\title{
Does Vitamin D cause atopy?
}

\author{
Valeria Andrea Zúñiga ${ }^{1}$ \\ ${ }^{1}$ Affiliation not available
}

October 19, 2021

VALERIA A. ZÚÑIGA (Orcid ID :https://orcid.org/0000-0002-9327-6588)

BLANCA BAZAN-PERKINS (Orcid ID :https: // orcid. org/0000-0003-1331-6349)

\section{To the Editor,}

Covid-19, caused by the severe acute respiratory syndrome coronavirus 2 , has brought threats to public health and has caused millions of deaths to date. It is suggested that a cytokine storm in Covid-19 is associated with greater mortality and clinical deterioration, attributing severe cases to the increase of interleukin (IL) -1 , tumor necrosis factor (TNF) $-\mathrm{a}$, interferon (IFN) $-\gamma$ and IL-6. ${ }^{1}$

Since the onset of the pandemic due Covid-19, evidence has indicated that vitamin D (VD) deficiency is associated with a preeminent incidence of infection ${ }^{2}$ and severity of Covid-19. As a consequence, sales of vitamin supplements have increased during the pandemic, including VD, due to its possible prophylactic or therapeutic value. ${ }^{3}$

Prohormone and VD can be obtained from endogenous production prompted by ultraviolet B radiation, from supplements, and from the diet. VD has multiple regulatory effects in the human body (figure 1), since there is evidence of the presence of its receptor in different tissues. ${ }^{4} \mathrm{VD}$ acts as a regulator of mineral homeostasis considering its effects on parathyroids, bone and intestine and has a variety of other biological functions, including immunological. ${ }^{5}$

For this reason, it is possible to have effects on innate and adaptive immunity, allowing the induction of monocyte and macrophage signaling, especially on antimicrobial peptides such as cathelicidins and $\beta$ defensin 2. Likewise, VD enables the inhibition of both B and T cells, decreases IL-1, IL-6, TNF-a and reduces antigen presenting cells such as dendritic cells. ${ }^{5}$ Evidence highlights that vitamin D3 generates a shift from an inflammatory T-helper (Th) 1-cell response to a pro-tolerogenic Th2 response with an arrest of cytotoxic T lymphocyte infiltration and an increase in CD4+ CD25+ T regulatory cells (Tregs). ${ }^{5}$ Hence, the possible development of atopy is suspected in people who consume VD in excess.

Atopy refers to the disposition of developing an immune hyperresponsiveness against allergens and antigens, leading to $\mathrm{CD} 4+\mathrm{Th} 2$ polarization and immunoglobulin E (IgE) overproduction. ${ }^{6}$ However, an increase in atopy has not been seen due to the consumption of this vitamin.

Scrutinizing with the aforementioned, VD inhibits maturation, differentiation, and survival of dendritic cells. It also down-regulates major histocompatibility complex type II and costimulatory receptors CD40, CD80 and $\mathrm{CD} 86^{5}$, which are elevated in atopy ${ }^{7}$; hindering the interaction and activation of T cells. Moreover, B cell proliferation and differentiation, even towards $\operatorname{IgE}$, is reduced.

Additionally, VD induces regulatory T-lymphocytes, ${ }^{5}$ the latter being able to exhort immune tolerance by enhancing the secretion of IL-10 and transforming growth factor $\beta .^{7}$ 
The deterioration or absence of development of an allergic or atopic disease by people who consume VD, can be explained by the action of Tregs. The latter can subdue proliferation and activation of effector Th cells, such as Th2 or Th17, and impede functions and migration of Th1, thus IFN- $\gamma$, Th2, Th9 and Th17 cells. ${ }^{7}$ Responsively, Th2 cytokines get suppressed ${ }^{8}$ by action of Tregs during atopy, including mast cells, IgE, basophils, and eosinophils, ${ }^{9}$ as shown in figure 2 .

Tregs have suppressive mechanisms mediated by its inhibitory cytokines and its stimulatory signals such as CTLA-4. This receptor implements an immunoregulatory function, restraining $\mathrm{T}$ cell response by avoiding the union of CD28 T-cell costimulatory molecule with its ligands CD80 and CD86.

In conclusion, VD promotes immune homeostasis through Tregs, reducing pro-inflammatory cytokines clustering, regulating levels of anti-inflammatory cytokines and enhancing the production of antimicrobial peptides. In this way, the derivation of an atopic disease as a result of a supposed increase in Th2 lymphocytes is avoided due to the consumption of this vitamin.

\section{ACKNOWLEDGEMENTS}

None.

\section{CONFLICTS OF INTEREST}

The authors report no conflicts of interest.

\section{AUTHORS}

Valeria Andrea Zúñiga ${ }^{1}$

Blanca Bazan-Perkins ${ }^{2,3}$

${ }^{1}$ Instituto Tecnológico y de Estudios Superiores de Monterrey, Escuela de Medicina y Ciencias de la Salud, Monterrey, Nuevo León, México

${ }^{2}$ Instituto Nacional de Enfermedades Respiratorias, Ismael Cosío Villegas, Ciudad de México, Mexico

${ }^{3}$ Instituto Tecnológico de Estudios Superiores de Monterrey, Escuela de Medicina y Ciencias de la Salud, Ciudad de México, México

Correspondence

Email:valeria.andrea.zuniga@gmail.com

\section{ORCID}

Valeria Andrea Zúñiga (Orcid ID:https://orcid.org/0000-0002-9327-6588)

Blanca Bazan-Perkins (Orcid ID:https://orcid.org/0000-0003-1331-6349)

\section{REFERENCES}

1. Kim, J. S., Lee, J. Y., Yang, J. W., Lee, K. H., Effenberger, M., Szpirt, W., Kronbichler, A., \& Shin, J. I. (2021). Immunopathogenesis and treatment of cytokine storm in COVID-19. Theranostics,11(1), 316-329. https://doi.org/10.7150/thno.49713

2. Szarpak, L., Rafique, Z., Gasecka, A., Chirico, F., Gawel, W., Hernik, J., Kaminska, H., Filipiak, K. J., Jaguszewski, M. J., \& Szarpak, L. (2021). A systematic review and meta-analysis of effect of vitamin D levels on the incidence of COVID-19. Cardiology journal,28(5), 647-654. https://doi.org/10.5603/CJ.a2021.0072

3. Lordan, R., Rando, H. M., COVID-19 Review Consortium, \& Greene, C. S. (2021). Dietary Supplements and Nutraceuticals under Investigation for COVID-19 Prevention and Treatment. mSystems, 6(3), e00122-21. https://doi.org/10.1128/mSystems.00122-21

4. Wang, Y., Zhu, J., \& DeLuca, H. F. (2012). Where is the vitamin D receptor?. Archives of biochemistry and biophysics,523(1), 123-133. https://doi.org/10.1016/j.abb.2012.04.001 
5. Martens, P. J., Gysemans, C., Verstuyf, A., \& Mathieu, A. C. (2020). Vitamin D's Effect on Immune Function. Nutrients, 12(5), 1248. https://doi.org/10.3390/nu12051248

6. Justiz Vaillant, A. A., Modi, P., \& Jan, A. (2021). Atopy. InStatPearls. StatPearls Publishing.

7. Boonpiyathad, T., Sözener, Z. C., Akdis, M., \& Akdis, C. A. (2020). The role of Treg cell subsets in allergic disease. Asian Pacific journal of allergy and immunology, 38(3), 139-149. https://doi.org/10.12932/AP-030220-0754

8. Borzutzky, A., \& Camargo, C. A., Jr (2013). Role of vitamin D in the pathogenesis and treatment of atopic dermatitis. Expert review of clinical immunology, 9(8), 751-760. https://doi.org/10.1586/1744666X.2013.816493

9. Martín-Orozco, E., Norte-Muñoz, M., \& Martínez-García, J. (2017). Regulatory T Cells in Allergy and Asthma. Frontiers in pediatrics, 5, 117. https://doi.org/10.3389/fped.2017.00117

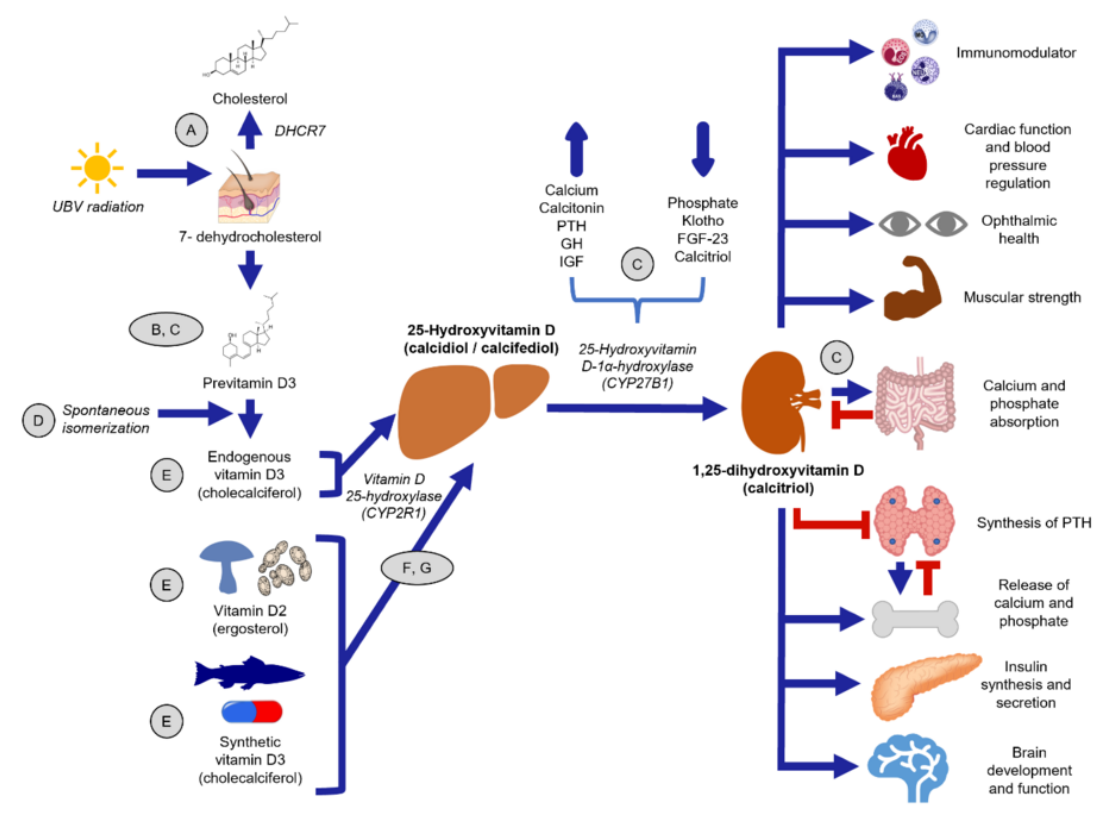

FIGURE 1. Vitamin D (VD) synthesis and its effects.

VD is obtained through the skin production or by alimentary consumption. 7-dehydrocholesterol, which can be transformed to cholesterol, ${ }^{\mathrm{A}}$ converts to previtamin $\mathrm{D} 3^{\mathrm{B}, \mathrm{C}}$ through ultraviolet $\mathrm{B}$ radiation. Via spontaneous isomeration, ${ }^{\mathrm{D}}$ precholecalciferol changes to cholecalciferol. ${ }^{\mathrm{E}}$ VD can be obtained from food, both of animal (cholecalciferol) and plant origin (ergocalciferol). ${ }^{\mathrm{E}}$ Cholecalciferol is metabolized in the liver to 25-hydroxyvitamin $\mathrm{D}{ }^{\mathrm{F}, \mathrm{G}}$ The active form of $\mathrm{VD}, 1,25$-dihydroxyvitamin $\mathrm{D}$, is obtained in the kidneys by the enzyme 25-Hydroxyvitamin D-1 $\alpha$-hydroxylase (which, in turn, is regulated by stimuli). ${ }^{\mathrm{C}}$ Calcitriol has diverse effects on different tissues. ${ }^{\mathrm{C}}$

1. Prabhu, A. V., Luu, W., Sharpe, L. J., \& Brown, A. J. (2016). Cholesterol-mediated Degradation of 7-Dehydrocholesterol Reductase Switches the Balance from Cholesterol to Vitamin D Synthesis. The Journal of biological chemistry, 291(16), 8363-8373.https://doi.org/10.1074/jbc.M115.699546

2. Wacker, M., \& Holick, M. F. (2013). Sunlight and Vitamin D: A global perspective for health. Dermatoendocrinology, 5(1), 51-108.https://doi.org/10.4161/derm.24494

3. Baeke, F., Takiishi, T., Korf, H., Gysemans, C., \& Mathieu, C. (2010). Vitamin D: modulator of the immune system. Current opinion in pharmacology, 10(4), 482- 
496.https://doi.org/10.1016/j.coph.2010.04.001

4. Tian, X. Q., \& Holick, M. F. (1995). Catalyzed thermal isomerization between previtamin D3 and vitamin D3 via beta-cyclodextrin complexation. The Journal of biological chemistry,270(15), 87068711.https://doi.org/10.1074/jbc.270.15.8706

5. Martin J. M. (1988). Analysis of selected elements in tobacco by wavelength dispersive X-ray fluorescence spectrometry. Journal - Association of Official Analytical Chemists, 71(5), 1038-1041.

6. Sassi, F., Tamone, C., \& D'Amelio, P. (2018). Vitamin D: Nutrient, Hormone, and Immunomodulator. Nutrients, 10(11), 1656.https://doi.org/10.3390/nu10111656

7. Martens, P. J., Gysemans, C., Verstuyf, A., \& Mathieu, A. C. (2020). Vitamin D's Effect on Immune Function. Nutrients, 12(5), 1248.https://doi.org/10.3390/nu12051248
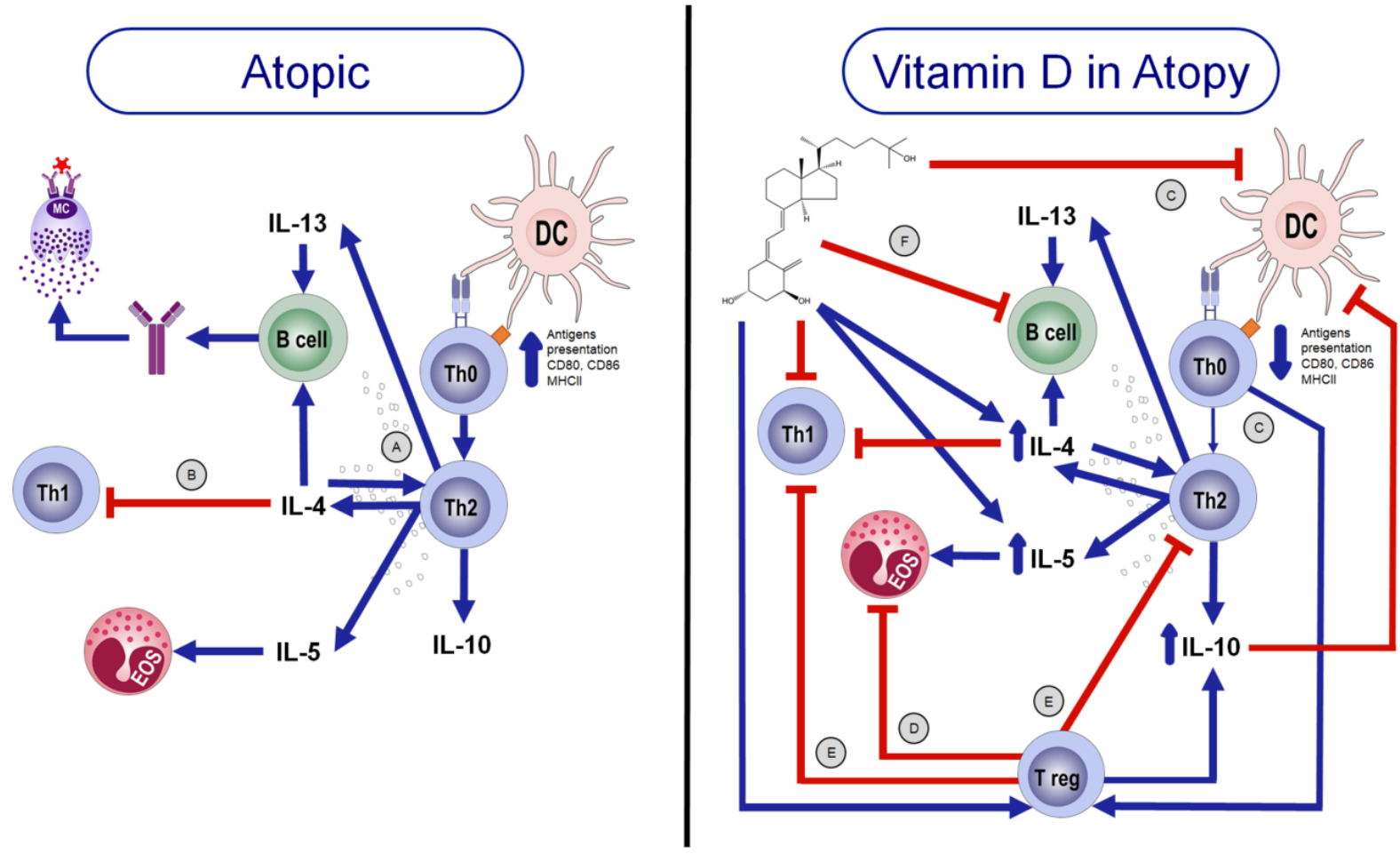

FIGURE 2. Vitamin D's (VD) regulatory mechanisms in atopy.

T-helper (Th)-2 cells, an atopy feature, release cytokines ${ }^{\mathrm{A}}$ such as interleukin (IL)-4, that inhibits Th1 cells generation, ${ }^{\mathrm{B}}$ IL-5, IL-10 and IL-13. Likewise, there is a notable elevation of antigens presentation, CD80/CD86 expression, major histocompatibility complex II (MHCII) action, mast cell (MC) release and eosinophils (EOS). VD regulates atopy's hyperresponsiveness through T regulatory cells (Tregs) differentiation, ${ }^{\mathrm{C}}$ suppressing $\mathrm{EOS}^{\mathrm{D}}$ and impeding Th1 and Th2 functions, which regulates cytokines of the latter. $^{\mathrm{E}}$ Additionally, VD suppresses dendritic cells $(\mathrm{DC})^{\mathrm{C}}$ and $\mathrm{B}$ cell differentiation, ${ }^{\mathrm{F}}$ reducing antibody production, including IgE, and antigen presentation.

1. Justiz Vaillant, A. A., Modi, P., \& Jan, A. (2021). Atopy. InStatPearls. StatPearls Publishing.

2. Lazarski, C. A., Ford, J., Katzman, S. D., Rosenberg, A. F., \& Fowell, D. J. (2013). IL-4 attenuates Th1-associated chemokine expression and Th1 trafficking to inflamed tissues and limits pathogen clearance. PloS one, 8(8), e71949.https://doi.org/10.1371/journal.pone.0071949

3. Martens, P. J., Gysemans, C., Verstuyf, A., \& Mathieu, A. C. (2020). Vitamin D's Effect on Immune Function. Nutrients, 12(5), 1248.https://doi.org/10.3390/nu12051248 
4. Martín-Orozco, E., Norte-Muñoz, M., \& Martínez-García, J. (2017). Regulatory T Cells in Allergy and Asthma. Frontiers in pediatrics, 5, 117.https://doi.org/10.3389/fped.2017.00117

5. Boonpiyathad, T., Sözener, Z. C., Akdis, M., \& Akdis, C. A. (2020). The role of Treg cell subsets in allergic disease. Asian Pacific journal of allergy and immunology, 38(3), 139149.https://doi.org/10.12932/AP-030220-0754

6. Charoenngam, N., \& Holick, M. F. (2020). Immunologic Effects of Vitamin D on Human Health and Disease. Nutrients, 12(7), 2097.https://doi.org/10.3390/nu12072097 